\title{
Structural Changes and Purchasing Power Parity in Turkish Exchange Rates
}

Türk Döviz Kurlarında Yapısal Değişiklikler ve Satın Alma Gücü Paritesi

\author{
Doç. Dr. İlhan KÜÇÜKKAPLAN ${ }^{1}$, Prof. Dr. Hüseyin AĞIR ${ }^{2}$, Arş. Gör. Çağın KARUL ${ }^{3}$, \\ Arş. Gör. Ahmet KONCAK ${ }^{4}$
}

\begin{abstract}
We re-examine the purchasing power parity (PPP) hypothesis for Turkey by concentrating on modelling structural changes as sharp (with dummy variables) and smooth (with a Fourier approximation) process. The results show (i) more evidence in favor of PPP hypothesis when structural changes are taken into account and (ii) modelling the shifts with different approaches plays a crucial role for policy implications.
\end{abstract}

Keywords: PPP hypothesis, structural shifts, Turkey

Paper Type: Research paper

\section{Özet}

Bu çalışmada, Türkiye için satın alma gücü paritesi (PPP) hipotezi, ani (kukla değişkenlerle) ve kademeli süreç (Fourier yaklaşımı ile) modelleme üzerine yoğunlaşarak, yapısal değişiklikler yeniden incelenmektedir. Sonuçlar (i) yapısal değişiklikler göz önüne alındığında PPP hipotezi lehine daha fazla kanıt göstermektedir ve (ii) farklı yaklaşımlarla değişimlerin modellenmesi politika sonuçları için çok önemli bir rol oynamaktadır.

Anahtar Kelimeler: Satın alma gücü paritesi hipotezi, yapisal değişiklik, Türkiye

Makale Türü: Araştırma makalesi

\section{Introduction}

After the 2001 economic crisis, Turkey put into effect the flexible exchange rate regime instead of the pegged regime. Nonetheless, intervention on exchange rate markets is an active policy tool of Central Bank of the Republic of Turkey (CBRT) to achieve inflation target and to maintain financial stability. Determining the dynamics of Turkish exchange rates plays a crucial role for the monetary policy and hence has recently attracted a great deal of interest.

\footnotetext{
${ }^{1}$ Pamukkale Üniversitesi, ikkaplan@pau.edu.tr, Orcid ID: https://orcid.org/0000-0001-6926-3659

${ }^{2}$ Kahramanmaraş Sütçü İmam Üniversitesi, huseyinagir@ksu.edu.tr, Orcid ID: https://orcid.org/0000-0003-1642-2876

${ }^{3}$ Ankara Yıldırım Beyazıt Üniversitesi , ckarul@pau.edu.tr, Orcid ID: https://orcid.org/0000-0002-5856-930X

${ }^{4}$ Abant İzzet Baysal Universitesi, akoncak@ibu.edu.tr, Orcid ID: https://orcid.org/0000-0002-4445-6128 
The purchasing power parity (PPP) hypothesis is one of the prominent theoretical arguments to explain the dynamics of exchange rates. Developments in unit root analysis have led researchers to re-examine PPP by investigating stationarity of real exchange rates. One explanation of failure to PPP is low power of the conventional unit root tests which are not able to detect mean reversion of exchange rates exhibiting structural shifts and nonlinearity (Bahmani-Oskooee et al., 2014). The literature for Turkey does not show a clear-cut evidence ${ }^{5}$ and this lack of consensus provides a room to re-test PPP within the context of new testing procedures.

This paper re-investigates PPP in Turkey by employing a battery of unit root and stationarity tests which takes into account structural changes as sharp and smooth process. We hence aim to contribute to the literature by modelling structural changes in exchange rates with different modelling approaches. Results indicate the importance of not only accounting for but also the modelling strategy of structural changes in testing procedures. We discover a more evidence in favor of validity of PPP when the structural shifts are taken into account and find out modelling the shifts as sharp or smooth process plays a crucial role for policy implications. . This finding provides a new evidence regarding the nature of the shocks to Turkish exchange rates.

\section{Testing Procedures}

The common approach for testing PPP is to carry out unit root analysis on the real exchange series that stationarity supports an evidence in favor of PPP. The econometric analysis starts with the conventional (no-shift) regression model given by

$$
\Delta \mathrm{y}_{\mathrm{t}}=\mathrm{z}_{\mathrm{t}}^{\prime} \delta+\alpha \mathrm{y}_{\mathrm{t}-1}+\varepsilon_{\mathrm{t}}
$$

where $Z_{t}$ includes the deterministic terms $[1, t]$ and $\varepsilon_{t}$ is the error term. The unit root null hypothesis $\left(\mathrm{H}_{0}: \alpha=0\right)$ is tested against the stationarity alternative $\left(\mathrm{H}_{1}: \alpha<0\right)$. The $\tau$ statistic developed by Dicker and Fuller (1981) is the t-ratio of $\alpha$.

Testing stationarity null hypothesis instead of unit root is useful to confirm results from tests with a stationarity alternative (Becker et al., 2006). In equation (1), the null hypothesis of stationarity $\left(\mathrm{H}_{0}: \alpha<0\right)$ is tested against the alternative hypothesis of unit root $\left(\mathrm{H}_{1}: \alpha=0\right)$. The so-called KPSS statistic developed by Kwiatkowski et al. (1992) is defined as $L M=\frac{\sum_{t=1}^{T} s_{t}^{2}}{\widetilde{\sigma}_{\varepsilon}^{2}}$ where $\tilde{S}_{t}=\sum_{j=1}^{t} \tilde{\varepsilon}_{j}$ is the partial sum of OLS residuals and $\tilde{\sigma}_{s}^{2}$ is the estimated long-run variance of $\varepsilon_{t}$ given by $\sigma_{s}^{2}=\lim _{T \rightarrow \infty} T^{-1} E\left(S_{T}^{2}\right)$.

\footnotetext{
${ }^{5}$ See Adiguzel at al. (2014) and Karagoz and Sarac (2016) for a detailed survey of the empirical studies on Turkey.
} 
$\mathrm{Z}_{\mathrm{t}}$ is assumed not to have any structural changes in the no-shift model, but ignoring structural shifts leads to low power in $\tau$ statistic (Perron, 1989) and size distortions in KPSS test (Lee et al., 1997). $Z_{t}$ is described as $\left[1, t, D_{1 t}, D_{1 t}\right]$ in order to allow a sharp-shift (sudden) change. To extend one break model for two changes, $Z_{t}$ is given by $\left[1, t, \mathrm{DU}_{1 \mathrm{t}}, \mathrm{DT}_{1 \mathrm{t}}, \mathrm{DU}_{2 \mathrm{t}}, \mathrm{DT}_{2 \mathrm{t}}\right]$, where $\mathrm{DU}_{\mathrm{it}}=0$ for $\mathrm{t} \leqslant \mathrm{T}_{\mathrm{Bi}}$ and 1 otherwise and $\mathrm{DT}_{\mathrm{it}}=0$ for $\mathrm{t} \leqslant \mathrm{T}_{\mathrm{Bi}}$ and $\mathrm{t}-\mathrm{T}_{\mathrm{Bi}}$ otherwise and $\mathrm{T}_{\mathrm{Bi}}(\mathrm{i}=1,2)$ shows the break dates. In the literature on unit root null hypothesis, ZA (Zivot and Andrews, 1992) allow one break and NP (Narayan and Popp, 2010) extend the testing framework for two breaks. In the literature on stationarity null hypothesis, Kurozumi (2002) allows a break in the KPSS test and CS (Carrion-i-Silvestre and Sansó, 2007) account for two breaks. The location of break $\left(\mathrm{T}_{\mathrm{Bi}}\right)$ is endogenously determined to be where the test statistic is minimized (i.e., the most negative) by a grid search procedure by considering all possible break points as $\widehat{\delta}=\operatorname{inf\tau }(\delta)$ where $\delta=\mathrm{T}_{\mathrm{Bi}} / \mathrm{T}$ and $\delta \in[0,1]$. Finally, $\tau$ statistic with structural shifts does not follow the asymptotic t-distribution and hence the simulated critical values are used.

The sharp-shift models are based on the dummy variable approach which entails knowing a priori the number, dates and form of breaks. In practice, it is difficult to have this information and moreover economic series may contain multiple smooth breaks at unknown dates. For the stationarity analysis, BEL (Becker et al., 2006) use a Fourier approximation for $Z_{t}$ which does not require selecting the dates, number, and form of the breaks. The Fourier expansion for $Z_{t}$ is described as $\left[1, t, \sin \left(\frac{2 \pi k t}{T}\right), \cos \left(\frac{2 \pi k t}{T}\right)\right]$ where $k$ represents an integer frequency. EL (Enders and Lee, 2012) recently develop the unit root statistic by employing a Fourier approximation.

\section{Findings}

The real exchange rates are constructed for the major trading partners ${ }^{6}$ (Canada, Denmark, Eurozone, Japan, Norway, Saudi Arabia, Sweden, Switzerland, United Kingdom, and USA) from January 2002 to December 2016 ${ }^{7}$. The real exchange rate $y_{t}=e_{t}+p_{t}^{*}-p_{t}$ where $e$ is the log of nominal exchange rate, $p^{*}(p)$ is the log of foreign (Turkish) consumer price index that are retrieved from IFS and CBRT's EVDS data base.

Table 1 reports the results. ADF test shows that PPP seems to be valid only for Norway in the no-shift model. When we account for one-sharp break, ZA test supports PPP for six countries (Denmark, Japan, Norway, Sweden, Switzerland, and UK). Moreover, the

\footnotetext{
${ }^{6}$ The trading partners explain more than 95 of Turkish trade as of 2016.

${ }^{7}$ We start the period from January 2002 because the euro circulation for cash payments were started on 1 January 2002.
} 
two-breaks test of NP indicates the validity of PPP for all countries. The KPSS test shows that the null of stationarity cannot be rejected for Canada, Denmark, Eurozone, and Norway where PPP holds. If we account for sharp shifts, Kurozumi (2002) and supports PPP for all countries (except UK). With respect to the break dates, it seems difficult to draw a general conclusion from both unit root and stationarity tests which indicate very different time points for each country. If the structural changes are modelled as a gradual/smooth process by means of a Fourier approximation, EL proves PPP for six countries (Denmark, Eurozone, Norway, Sweden, Switzerland, and UK) which are all the European Union countries. BEL stationarity test indicates the validity of PPP only with two exceptions (Japan and Sweden).To sum up, controlling for shifts plays a crucial role for testing PPP in Turkey and different approximations how to modelling breaks lead to changes in inferences. We find a more evidence in favor of PPP by accounting for structural shifts. An interesting finding also is that there is a strong evidence on the validity of PPP in the case of European countries (except Sweden).

Table 1. Results

\begin{tabular}{|c|c|c|c|c|c|c|c|c|}
\hline & No-shift & & harp-shift & & & & Smoot & \\
\hline Unit root tests $^{a}$ & $\mathrm{ADF}$ & ZA & $\begin{array}{l}\text { Break } \\
\text { Date }\end{array}$ & NP & $\begin{array}{l}\text { First } \\
\text { Break Date }\end{array}$ & $\begin{array}{l}\text { Second } \\
\text { Break Date }\end{array}$ & EL & $k^{c}$ \\
\hline Canada & -1.803 & -4.509 & 2005M03 & -5.185 & 2006M01 & 2011M11 & -3.043 & 1 \\
\hline Denmark & -2.938 & -5.413 & 2005M04 & -7.110 & 2008M10 & 2011M04 & -4.321 & 1 \\
\hline Eurozone & -3.016 & -4.568 & 2007M07 & -6.632 & 2008M10 & 2011M04 & -4.468 & 1 \\
\hline Japan & -2.563 & -5.953 & 2008M07 & -7.357 & 2008M07 & 2012M10 & -3.510 & 2 \\
\hline Norway & -3.445 & -5.354 & 2004M03 & -7.386 & 2004M03 & 2010M10 & -4.672 & 1 \\
\hline Saudi Arabia & -2.404 & -3.634 & 2007M02 & -5.900 & 2008M07 & 2013M08 & -3.080 & 1 \\
\hline Sweden & -2.653 & -5.487 & 2010M10 & -7.180 & 2006M03 & 2010M10 & -4.296 & 1 \\
\hline Switzerland & -2.533 & -5.953 & 2008M07 & -6.462 & 2008M07 & 2010M10 & -4.107 & 1 \\
\hline UK & -2.337 & -5.169 & 2009M10 & -6.886 & 2006M03 & 2009M10 & -4.926 & 1 \\
\hline USA & -1.955 & -3.569 & 2007M07 & -5.319 & 2007M07 & 2012M08 & -3.635 & 1 \\
\hline Stationarity tests ${ }^{b}$ & KPSS & Kurozumi & $\begin{array}{l}\text { Break } \\
\text { Date }\end{array}$ & $\mathrm{CS}$ & $\begin{array}{l}\text { First } \\
\text { Break Date }\end{array}$ & $\begin{array}{l}\text { Second } \\
\text { Break Date }\end{array}$ & BEL & \\
\hline Canada & 0.097 & 0.030 & 2010M12 & 0.030 & 2007M11 & 2011M01 & 0.044 & 1 \\
\hline Denmark & 0.117 & 0.025 & 2007M05 & 0.019 & 2002M05 & 2008M02 & 0.023 & 1 \\
\hline Eurozone & 0.118 & 0.024 & 2011M01 & 0.021 & 2002M05 & 2008M02 & 0.020 & 1 \\
\hline Japan & 0.189 & 0.024 & 2008M09 & 0.024 & 2008M09 & 2012M12 & 0.169 & 2 \\
\hline Norway & 0.117 & 0.019 & 2010M12 & 0.038 & $2003 \mathrm{M} 03$ & 2011M01 & 0.024 & 1 \\
\hline Saudi Arabia & 0.750 & 0.045 & 2008M09 & 0.033 & 2008M09 & 2012M12 & 0.027 & 1 \\
\hline Sweden & 0.149 & 0.024 & 2010M12 & 0.023 & 2002M05 & 2010M12 & 0.050 & 1 \\
\hline Switzerland & 0.229 & 0.031 & 2008M09 & 0.016 & 2002M05 & 2008M02 & 0.034 & 1 \\
\hline UK & 0.364 & 0.070 & 2010M12 & 0.039 & 2010M12 & 2015M05 & 0.026 & 1 \\
\hline USA & 0.581 & 0.032 & 2007M09 & 0.027 & 2008M09 & 2012M11 & 0.028 & 1 \\
\hline
\end{tabular}

Bold number supports PPP at least at $10 \%$.

a: Based on t-stat significance rule as in Zivot and Andrews (1992). 
b: Based on Bartlett kernel rule in Sul et al. (2005).

c: Number of Fourier frequency $(k)$ is determined by minimizing SSR (see, Becker et al., 2006).

ADF: $\quad \Delta y_{t}=\mu+\beta t+\alpha y_{t-1}+\sum_{j=1}^{p} \beta_{j} \Delta y_{t-j}+\varepsilon_{t}$.

CV (critical value): -3.18 (10\%).

ZA: $\quad \Delta y_{\mathrm{t}}=\mu+\beta t+\mu_{1} D U_{1 \mathrm{t}}+\beta_{1} D T_{1 \mathrm{t}}+\alpha y_{\mathrm{t}-1}+\sum_{j=1}^{p} \beta_{j} \Delta y_{\mathrm{t}-j}+\varepsilon_{\mathrm{t}}$.

CV: -4.82 (10\%) (Table 4; Zivot and Adrews, 1992: 257).

NP:

$\Delta y_{\mathrm{t}}=\mu+\beta \mathrm{t}+\mu_{1} D U_{1 \mathrm{t}}+\beta_{1} D T_{1 \mathrm{t}}+\mu_{2} D U_{2 \mathrm{t}}+\beta_{2} D T_{2 \mathrm{t}}+\alpha y_{\mathrm{t}-1}+\sum_{j=1}^{p} \beta_{j} \Delta y_{t-j}+\varepsilon_{\mathrm{t}}$.

CV: Table 2; Narayan and Popp (2010: 1429).

EL: $\quad \Delta y_{t}=\mu+\beta t+\theta \sin (2 \pi k t / T)+\varphi \cos (2 \pi k t / T)+\alpha y_{t-1}+\sum_{j=1}^{p} \beta_{j} \Delta y_{t-j}+\varepsilon_{\mathrm{t}}$.

CV: $-4.05(10 \%)$ for $k=1 ;-3.71(10 \%)$ for $k=2 ;-3.44(10 \%)$ for $k=3$ (Table $1 \mathrm{a}$; Enders and Lee, 2012: 197).

KPSS: $y_{\mathrm{t}}=\mu+\beta t+\varepsilon_{\mathrm{t}}$.

CV: 0.216 (10\%) (Table 1; Kwiatkowski et al., 1992: 166).

Kurozumi: $y_{\mathrm{t}}=\mu+\beta t+\mu_{1} D U_{1 \mathrm{t}}+\beta_{1} D T_{1 \mathrm{t}}+\varepsilon_{\mathrm{t}}$.

CV: 0.32862 (10\%) (Table 2, Case 3; Kurozumi, 2002:76).

CS: $\quad y_{\mathrm{t}}=\mu+\beta \mathrm{t}+\mu_{1} D U_{1 \mathrm{t}}+\beta_{1} D T_{1 \mathrm{t}}+\mu_{2} D U_{2 \mathrm{t}}+\beta_{2} D T_{2 \mathrm{t}}+\alpha y_{\mathrm{t}-1}+\varepsilon_{\mathrm{t}}$.

CV: Table 2, Model CC; Carrion-i-Silvestre and Sanso, 2007: 111).

BEL $: y_{t}=\mu+\beta t+\theta \sin (2 \pi k t / T)+\varphi \cos (2 \pi k t / T)+\varepsilon_{t}$.

CV: Table 1a; Becker et al. (2006: 389).

\section{Conclusion}

We re-examine PPP in Turkey by paying attention to controlling for structural shifts by means of the recent developments in time series analysis. The results find out that controlling for structural shifts plays an important role in order to determine the behavior of Turkish exchange rates. This finding implies that the different testing strategies result in the different inferences and policy implications. While the conventional no-shift model indicates the validity of PPP only for Norway, the sharp and smooth shift models show more evidence, specifically in European countries.

\section{References}

Adigüzel, U, Şahbaz, A., Özcan, C. C. and Nazlioğlu, Ş. (2014). "The Behavior of Turkish Exchange Rates: A Panel Data Perspective", Economic Modelling, 42, pp. 117-185.

Bahmani-Oskooee, M., Chang, T., Liu W. C. (2014). "Revisiting Purchasing Power Parity in 34 OECD Countries: Sequential Panel Selection Method", Applied Economics Letters 21(18), pp.1283-1287.

Becker, R., Enders, W. and Lee, J. (2006). "A Stationarity Test in The Presence of an Unknown Number of Smooth Breaks", Journal of Time Series Analysis 27, pp. 381-409.

Carrion-I-Silvestre, J. L. and Sansó, A. (2007). "The KPSS Test with Two Structural Breaks", Spanish Economic Review 9(2), pp. 105-127.

Dickey, D. A. and Fuller, W. A. (1981). "Likelihood Ratio Statistics for Autoregressive Time Series with a Unit Root”, Econometrica, 49, pp. 1057-1072. 
Enders, W. and Lee, J. (2012). "The Flexible Fourier Form and Dickey-Fuller Type Unit Root Tests", Economics Letters 117, pp. 196-199.

Karagöz, K. ve Saraç, B. (2016). "Testing the Validity of PPP Theory for Turkey: Nonlinear Unit Root Testing”, Procedia Economics and Finance 38, pp. 458 - 467.

Kurozumi, E. (2002). "Testing for Stationarity with a Break", Journal of Econometrics 108(1), pp. 63-99.

Kwiatkowski, D., Phillips, P. C.B., Schmidt, P. and Shin, Y. (1992). "Testing the Null Hypothesis of Stationary against the Alternative of a Unit Root", Journal of Econometrics 54, pp. 159-178.

Lee, J., Huang, C. J. and Shin, Y. (1997). "On Stationary Tests in the Presence of Structural Breaks", Economics Letters 55, pp. 165-172.

Narayan, P. K. and POPP, S. (2010). "A New Unit Root Test with Two Structural Breaks in Level and Slope at Unknown Time", Journal of Applied Statistics 37(9), pp. 1425-1438.

Perron, P. (1989). "The Great Crash, the Oil Price Shock, and the Unit Root Hypothesis", Econometrica 57, pp. 1361-1401.

Sul, D., Phillips, P. and Choi, C. (2005). "Prewhitening Bias in HAC Estimation", Oxford Bulletin of Economics and Statistics 67(4), pp. 517-546.

Zivot, E. and Andrews, D.W.K. (1992). "Further Evidence on the Great Crash, the Oil-Price Shock, and the Unit-Root Hypothesis", Journal of Business \& Economics- Statistics 10, pp. 251-270. 